\title{
Forest strips left along water and bog can be valuable for birds. A case of experimental cutting.
}

\author{
Sigmund Hågvar \& Bjørn Tore Bækken
}

Hågvar, S. \& Bækken, B. T. 2005. Forest strips left along water and bog can be valuable for birds. A case of experimental cutting. - Ornis Norvegica 28: 51-57.

An experimental cutting was performed in Grue municipality, Hedmark, to study the value for birds of retaining a forest strip along bog and water. Two study areas of mature coniferous forest were selected, each 600 x $200 \mathrm{~m}$, with one of the long sides towards either water or bog. Before logging started, all bird territories were mapped during two years. In the third breeding season, a $50 \mathrm{~m}$ wide forest strip remained adjacent to water and bog, and in the fourth season a $25 \mathrm{~m}$ wide forest strip. Both along bog and water, the $25 \mathrm{~m}$ wide forest strip supported a species- and individual-rich bird fauna, with higher density than before cutting. This is in accordance with an extensive study in remaining forest strips adjacent to water and bogs in South-East Norway, where the authors adviced to set aside $30 \mathrm{~m}$ wide strips. Literature data indicate that the rich bird life in such buffer zones may be due to a concentration of insects blown in from the open clearcut area.

Sigmund Hågvar, Department of Ecology and Natural Resource Management, Box 5003, Agricultural University of Norway, NO-1432 As, Norway.E-mail: sigmund.hagvar@umb.no.Bjørn Tore Bakken, Liavegen 45, NO-2420 Trysil, Norway.E-mail: bjorn.tore.bekken@trysil.kommune.no.

\section{INTRODUCTION}

The retention of forest strips adjacent to water and bog has long been recommended in Fennoscandian forestry. Such buffer zones may be positive for terrestrial and aquatic biodiversity, for water quality and for aesthetic reasons (e.g. Nilsson 1992). Birdlife is often rich in forest close to water and bog (Hogstad 1967, Stauffer \& Best 1980, Johnson \& Brown 1990, Gates \& Giffen 1991, LaRue et al. 1995). In North America, several studies have been published during the last ten years on the value to bird fauna of retaining forest strips along rivers (e.g. Darveau et al. 1995, Dickson et al. 1995, Hodges \& Krementz 1996, Hagar 1999, Meiklejohn \& Hughes 1999, Whitaker \& Montevecchi 1999,
Lambert \& Hannon 2000, Whitaker et al. 2000). Even narrow strips may be rich in individuals, but contain mainly generalists and edge species. The American studies also demonstrate that the birdlife in such riparian buffer strips may depend strongly on forest type and climate. Therefore, recommendations on strip width should be based on local studies.

In Fennoscandian coniferous forest, several studies have been done on the effect of fragmentation on the bird fauna (e.g. Haila et al. 1987, Virkkala 1991,Edenius \& Sjöberg 1997, Tømmerås et al.2000). Also the edge effect between mature forest and clearcut has been studied (Hansson 1983, 1994). However, there was no systematic study on the value for birdlife of retaining forest 
strips of different width along water and bog until Hågvar et al. (2004). Based on 370 retained forest strips in south-east Norway, with widths ranging from 2 to $100 \mathrm{~m}$, they recommended to leave 30 $\mathrm{m}$ wide strips for the bird fauna. The present work is a continuation of this study, but with another approach. Instead of studying remaining strips after finished cutting, we gradually narrowed two strips by experimental cutting. The changes in bird fauna was recorded both on the increasing clearcut and in the narrowing buffer strip.

\section{MATERIAL AND METHODS}

Experimental clear-cutting was performed in mature coniferous forest near Bjørsjøberget, Grue municipality, Hedmark county, at altitudes between 400 and $500 \mathrm{~m}$. Both study areas were $600 \times 200 \mathrm{~m}$, with one of the longest sides representing an edge towards a lake or a bog. The dominating forest type towards water was spruce (Picea abies (L.) Karst.), mainly with Vaccinium myrtillus L., and towards bog pine (Pinus sylvestris L.) with some spruce and a mixture of V.myrtillus and Vaccinium vitis-idaea L. Close to water or bog, both sites had a more moist belt of approximately 25-50 m width, with a poorer and lower forest dominated by spruce and birch (Betula pubescens Ehrh.). It is a rather typical situation in SE Norway that such edges are both poorer and moister than the main stand behind.

Bird territories were mapped based on 9-13 censuses. Observations were made mainly in early morning between 05.00 and $09.00 \mathrm{~h}$ during the breeding season (May-June). Rainy or windy weather was avoided.

During two years before cutting (1987 and 1988), all bird territories were mapped on both study areas. In 1989, a $50 \mathrm{~m}$ wide forest strip was left after clearcutting during the preceeding winter, and in 1990, a $25 \mathrm{~m}$ wide strip. Also the bird fauna on the increasing clearcut area was mapped. Some small spruces were left for regeneration on the clearcut area towards water, and some large pines for seed production on the clearcut area towards bog.

A study area was also established in Maliskjæra forest reserve nearby, hoping to use it as a reference for natural year-to-year variations in bird densities. However, because changes from 1987 to 1988 were different in the reserve compared to the unlogged experimental sites, the use of reference area was abandoned. The main reason was that Fringilla montifringilla was absent from the reserve both years, while this species showed a strong peak in the two experimental plots in 1988.

\section{RESULTS}

Figure 1 visualizes the position of all territories recorded on the two experimental sites throughout the four-year study. Table 1 sums up the number of territories for different species, giving separate information about the territories situated in the outer $50 \mathrm{~m}$ belt closest to water or bog.

Figure 1 shows that during the two years before cutting (1987-88), there was no tendency for a higher bird density in the outer $50 \mathrm{~m}$ zone towards water or bog, than in the inner part of the experimental plots. Fringilla montifringilla was unusually common in 1988. This species is characteristic for high altitude forest and may show great yearly variations at the present altitude (Haftorn 1971).

In 1989, a $50 \mathrm{~m}$ wide forest strip remained both towards water and bog. The forest strip towards bog contained 9 territories of 5 species (Table 1). However, on the $150 \mathrm{~m}$ broad clearcut area behind, only four territories of two species were recorded: Two territories of the ground-nester Anthus trivialis and two of the tree-nester Fringilla coelebs, which could use the few remaining seed trees of pine. Next year (1990), when only a 25 $\mathrm{m}$ wide forest strip remained towards the bog, there were still rather few birds nesting on the 
UPPER PART: TOWARDS BOG

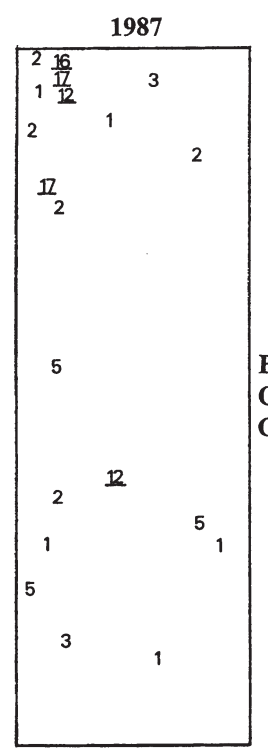

$200 \mathrm{~m}$ forest
1988

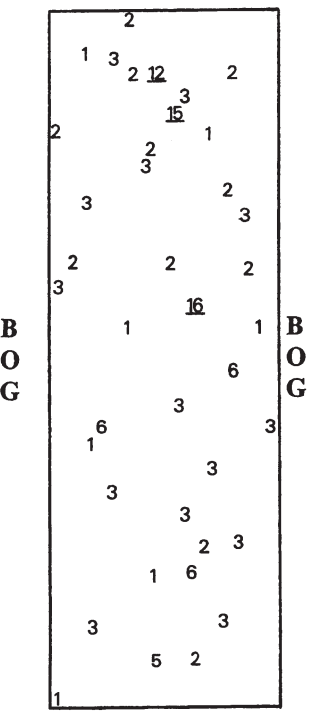

$200 \mathrm{~m}$ forest
1989

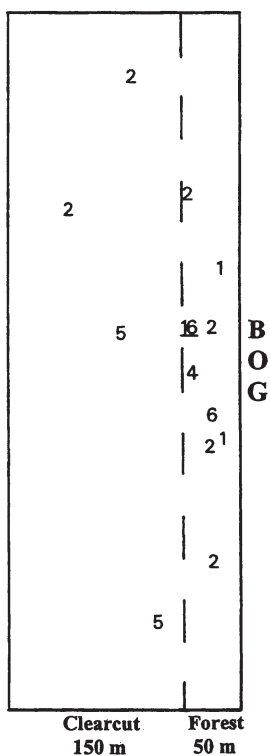

1990

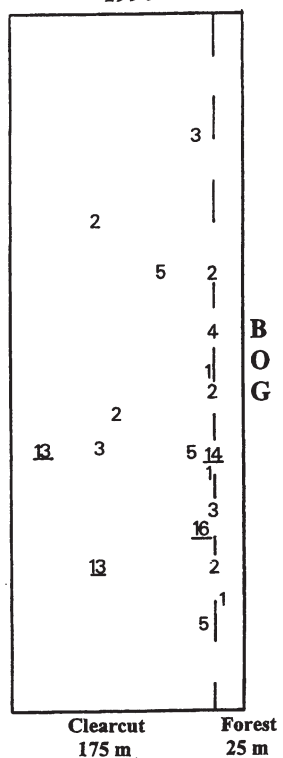

LOWER PART: TOWARDS WATER

1987

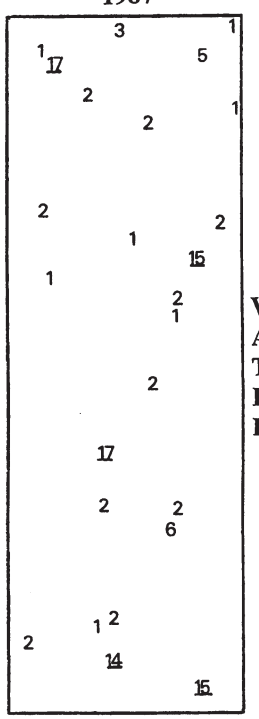

$200 \mathrm{~m}$ forest
1988

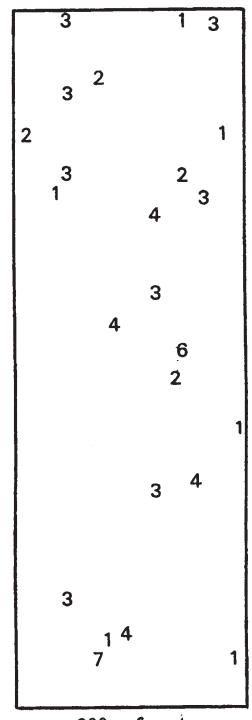

$200 \mathrm{~m}$ forest
1989

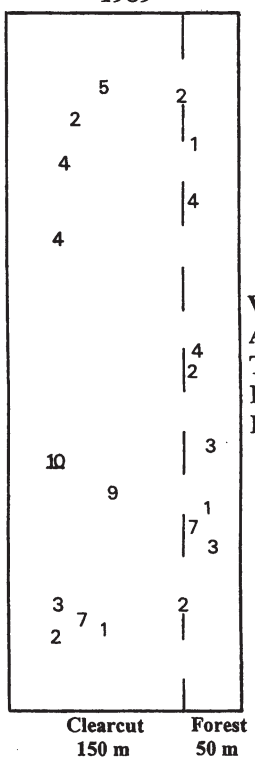

1990

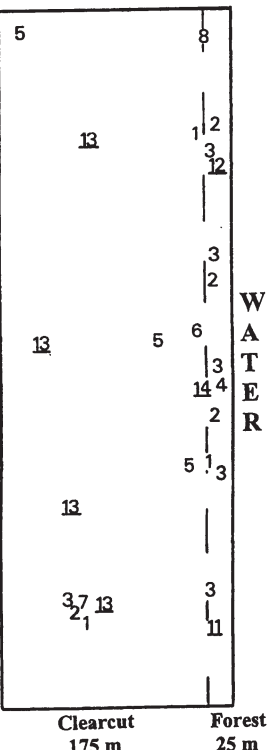

Figure 1. Centers of bird territories in two $600 \mathrm{~m}$ long and $200 \mathrm{~m}$ wide experimental areas during four successive years, one strip along a bog (upper part) and one along a lake (lower part). The years 1987 and 1988 were before experimental cutting, when the plots consisted of old forest, with continuous forest behind. In 1989, most of the experimental areas had been cut, leaving a $50 \mathrm{~m}$ wide and $600 \mathrm{~m}$ long forest strip adjacent to the bog and the lake. In 1990, the remaining forest strips were only $25 \mathrm{~m}$ wide. Some large pines for seed production had been left on the clearcut area near the bog, and a few youg spruce trees on the clearcut near the water. Species codes: 1 = Phylloscopus trochilus, $2=$ Fringilla coelebs, $3=$ Fringilla montifringilla, $4=$ Regulus regulus, $5=$ Anthus trivialis, $6=$ Erithacus rubecula, $7=$ Prunella modularis, $8=$ Parus montanus, 9 = Motacilla alba, 10 = Motacilla flava, $11=$ Ficedula hypoleuca, $12=$ Parus cristatus, $13=$ Saxicola rubetra, $14=$ Turdus philomelos, $15=$ Turdus merula, $16=$ Phoenicurus phoenicurus, $17=$ Certhia familiaris. Numbers higher than nine have been underlined. 
clearcut. Two of the territories belonged to Saxicola rubetra, a clearcut-specialist (Hansson 1994). However, an astonishing abundant and diverse bird fauna was recorded within the outer 50 m belt: 13 territories of 7 species (Table 1). It was sometimes difficult to decide which of these territories should be confined to the outer 25 meter belt with trees. But most of these 13 nests must have been situated in the $25 \mathrm{~m}$ wide forest strip, since 8 of them belonged to tree-nesters.

The number of territories in the remaining 50 m wide forest strip towards water in 1989 was somewhat higher than in the same zone before clearcutting. On the $150 \mathrm{~m}$ wide clearcut, some young spruce trees had been left for regeneration. This explains the presence of some tree-nesters there: F. coelebs, F. montifringilla, Regulus regulus and Prunella modularis. These species would have had no nesting possibilities on a really clearcut area, leaving only the groundnesting species there: A.trivialis, Phylloscopus trochilus, Motacilla alba and Motacilla flava, with one territory each. The last species prefers open areas. The situation demonstrates, however, that leaving a few young spruces makes the clearcut inhabitable for several tree-nesting species. Next year (1990), when only a 25 m wide forest strip remained towards water, we experienced a strong consentration of birds, quite parallell to the effect towards bog: as much as 17 territories of 10 species were found in the outer $50 \mathrm{~m}$ zone. At least 13 of the 17 nests must have been situated in the $25 \mathrm{~m}$ wide forest strip, since they belonged to tree-nesters. Also this year some tree-nesters bred in some small spruces left on the clearcut area (F.coelebs, F. montifringilla and $P$. modularis with one nest each). Otherwise, the large clearcut area contained only seven pairs of three ground-nesters: P. trochilus, A.trivialis and the clearcut-specialist $S$. rubetra.

\section{DISCUSSION}

The most remarkable result was the high density and diversity of breeding birds in, or along, the remaining $25 \mathrm{~m}$ wide forest strips in 1990. Figure
1 visualizes this phenomenon. As explained above, most birds recorded within the outer 50 $\mathrm{m}$ this year belonged to tree-nesters, and therefore nested in the $25 \mathrm{~m}$ wide buffer zone. Bird densities in the outer $50 \mathrm{~m}$ zone was considerably lower during the two years before cutting started. This was the case even though $F$. montifringilla had a high density in 1988 .

Because the owner left some young spruces on the clearcut towards water and a few seed-producing pines on the clearcut towards bog, certain tree-nesting birds were able to use the cut areas. This reduces the contrast in bird fauna between clearcut and forest strip, but illustrates that leaving a few trees allows more species to breed on the clearcut than only ground-nesters. Hansson $(1983,1994)$ has shown that open, Swedish clearcuts contain few species and a low abundance of birds.

Hågvar et al. (2004) made an extensive study of the bird fauna in remaining forest strips of different width along water and bog in south-east Norway. The highest densities of species and territories were found in 11-30 $\mathrm{m}$ wide strips, mean values in 11-20 m wide strips being insignificantly higher than in 21-30 m wide strips. They recommended buffer strips of about $30 \mathrm{~m}$ width, since narrower strips had fewer species and territories per $100 \mathrm{~m}$ strip length. The present experimental cutting confirms that a $25 \mathrm{~m}$ wide forest strip adjacent to water or bog may support a rather dense and species-rich bird fauna, exceeding the bird fauna in this belt before cutting. According to Hågvar et al. (2004), strips narrower than 10 $\mathrm{m}$ is of little value for bird life.

It is an open question whether the rich bird fauna associated with the $25 \mathrm{~m}$ wide strips was a permanent phenomenon, or a short-term crowding response due to the removal of the forest behind. Some North American studies have experienced a temporary crowding in forest strips during the first year after cutting (e.g. Darveau et al. 1995). However, Tømmeraas et al. (2000) failed to show any crowding effect immediately after cutting in a 
Table 1. Number of territories within two $600 \mathrm{~m}$ long and $200 \mathrm{~m}$ wide forest strips, one towards a bog and one towards a lake, during experimental cutting. The years 1987 and 1988 were before cutting, while a $50 \mathrm{~m}$ wide strip of forest was left in both places in 1989 and a $25 \mathrm{~m}$ wide strip in 1990. Each year, the total number of territories in the whole area of $600 \times 200 \mathrm{~m}$ is given, and the number situated in the $50 \mathrm{~m}$ wide zone closest to water or bog in parenthesis.

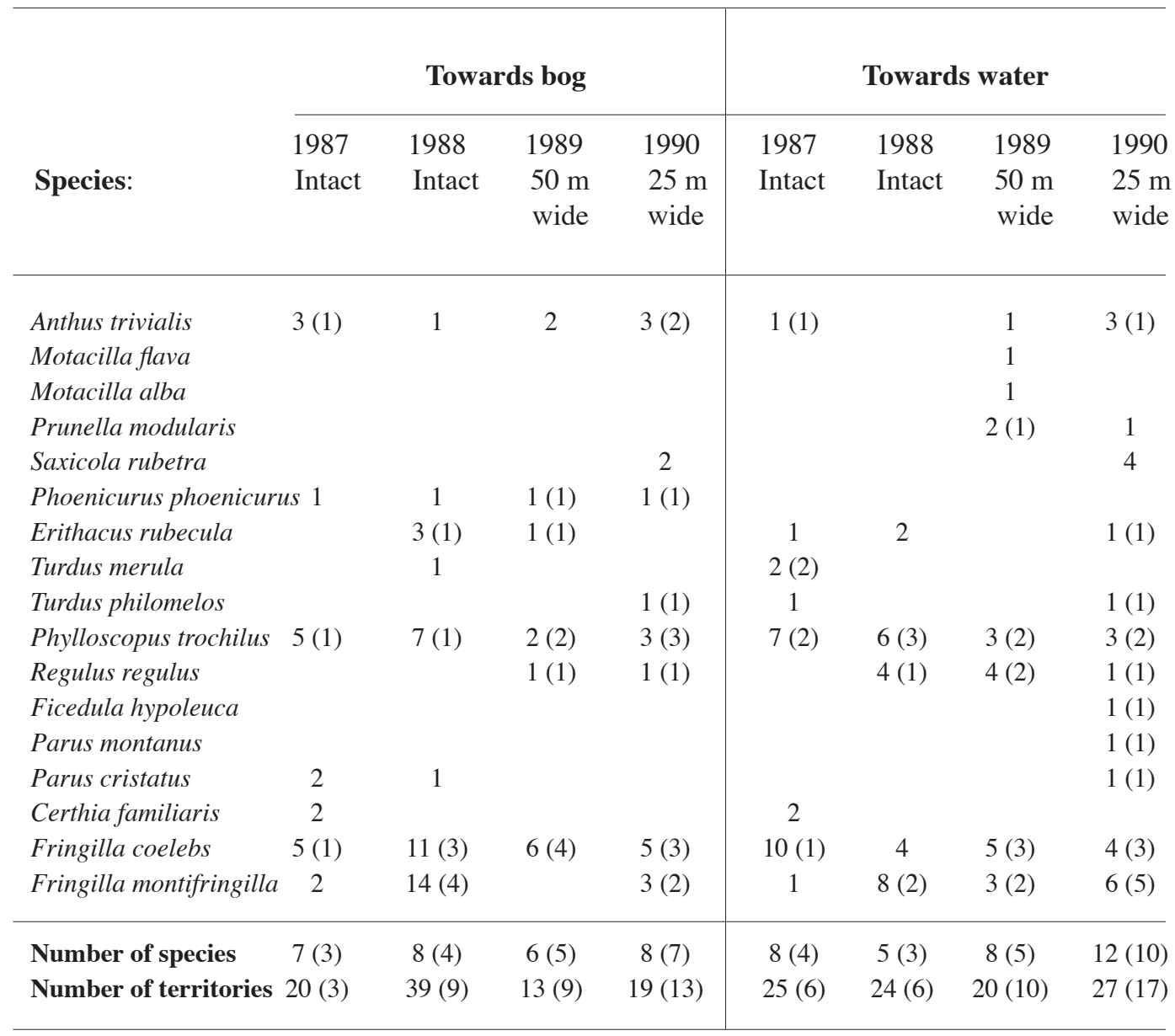


Norwegian fragmentation study in spruce forest. Since the strips studied by Hågvar et al. (2004) were more than one year old, the recorded high bird density in their 10-30 m wide strips was probably permanent.

Already Hansen (1983) suggested that the increased bird densities he recorded along the forest edge towards clearcuts could be due to increased availability of insect food, although he lacked insect data. Later, Whitaker et al. (2000) documented a high density of both birds and insects in riparian forest strips of balsam fir in Canada. They concluded that riparian buffer strips act as wind breaks, concentrating airborne insects blown in from adjacent open areas. In Finland, a rich invertebrate fauna in forest edges has been documented by Helle \&Muona (1985). In forest strips adjacent to water, insects hatching from water may also represent a food source (Gray 1993). On this background, a rich supply of insects is assumed to be a main reason for the rich bird fauna observed in the present study in and along $25 \mathrm{~m}$ wide forest strips.

During a ten year study, Thingstad (1997) found that the breeding success of $F$. hypoleuca was significantly poorer along a lake shore in Central Norway than in the more sheltered, innermost part of the same forest. This «lake effect» (Järvinen 1982) was related to more unfavourable climatic conditions certain years along the lake, with colder, wetter and more windy weather. In the present case it may be that an increased supply of insects in remaining forest strips along lakes may counteract the negative climatic effects of the vicinity to open water.

\section{ACKNOWLEDGEMENTS}

Grim Huset, Statskog, is heartily thanked for administrating the experimental cutting, and for lodging facilities. Economic support was given from the Nordic Forest Research Cooperation Committee and The Norwegian Forest Research Institute.

\section{SAMMENDRAG}

\section{Det har verdi for fuglelivet å sette igjen kant- soner av skog mot vann og myr}

For å studere verdien for fuglelivet av å sette igjen striper med skog mot vann og myr, ble eksperimentell hogst foretatt i Grue kommune, Hedmark. To studieområder, hver på 600 x 200 $\mathrm{m}$, ble valgt ut i hogstmoden barskog, med ene langsiden mot vann eller myr. Før hogst startet ble alle fuglerevirer kartlagt i 2 år. I den tredje hekkesesongen var det satt igjen en $50 \mathrm{~m}$ bred skogstripe mot henholdsvis vann og myr, og i den fjerde sesongen kun en $25 \mathrm{~m}$ bred stripe med trær. Både mot vann og myr viste det seg at den $25 \mathrm{~m}$ brede skogstripen ga grunnlag for en rik fuglefauna, med høyere arts- og individtetthet enn før hogst. Dette stemmer godt med en omfattende unders $\varnothing$ kelse på $\emptyset$ stlandet av fuglefaunaen i gjensatte kantsoner med ulik bredde, der man anbefalte å sette igjen $30 \mathrm{~m}$ brede buffersoner. Litteraturdata tyder på at den rike fuglefaunaen i slike kantsoner kan skyldes god mattilgang, idet insekter som blåses inn fra flaten trolig kan oppkonsentreres i kantsonen.

\section{REFERENCES}

Darveau, M., Beauchesne, P., Bélanger, L., Huot, J. \& LaRue, P. 1995. Riparian forest strips as habitat for breeding birds in boreal forest. - J. Wildl. Manag. 59: 67-78.

Dickson, J. G., Williamson, J. H., Conner, R. N. \& Ortego, B. 1995. Streamside zones and breeding birds in eastern Texas. - Wildl. Soc. Bull. 23: 750-755.

Edenius, L. \& Sjöberg, K. 1997. Distribution of birds in natural landscape mosaics of old-growth forests in northern Sweden: relations to habitat area and landscape context. - Ecography 20: 425-431.

Gates, J.E. \& Giffen, N. R. 1991. Neotropical migrant birds and edge effects at a forest-stream ecotone. - Wilson Bull. 103: 204-217.

Gray, L. J. 1993. Response of insectivorous birds to emerging aquatic insects in riparian habitats of a tallgrass prarie stream. - Am. Midl. Nat. 129: 288-300.

Haftorn, S. 1971. Norges fugler. Universitetsforlaget, Oslo. (In Norwegian). 
Hagar, J. C. 1999. Influence of riparian buffer width on bird assemblages in Western Oregon. - $J$. Wildl. Manag. 63: 484-496.

Hågvar, S., Nygaard, P. \& Bækken, B. T. 2004. Retention of forest strips for bird-life adjacent to water and bogs in Norway: Effect of different widths and habitat variables. - Scand.J.For. Res. 19: 1-14.

Haila, Y., Hanski, I. K. \& Raivio, S. 1987. Breeding bird distribution in fragmented coniferous taiga in southern Finland. - Ornis Fenn. 64: 90-106.

Hansson, L. 1983. Bird numbers across edges between mature conifer forest and clearcuts in Central Sweden. - Ornis Scand. 14: 97-103.

Hansson, L. 1994. Vertebrate distributions relative to clear-cut edges in a boreal forest landscape. - Landscape Ecol. 9: 105-115.

Helle, P. \& Muona, J. 1985. Invertebrate numbers in edges between clear-fellings and mature forests in northern Finland. - Silva Fenn. 19: 281-294.

Hodges, M. F. Jr. \& Krementz, D. G. 1996. Neotropical migratory breeding bird communities in riparian forests of different widths along the Altamaha river, Georgia. - Wilson Bull. 108: 496-506.

Hogstad, O. 1967. The edge effect on species and population density of some passerine birds. - Nytt Mag. Zool. 15: 40-43.

Järvinen, A. 1982. Influence of the lake shore on the reproduction of the Pied Flycatcher Ficedula hypoleuca, and the Redstart Phoenicurus phoenicurus in Finnish Lapland. - Ann. Zool. Fennici 19: 171-174.

Johnson, W. N. \& Brown, P. W. 1990. Avian use of a lakeshore buffer strip and an undisturbed lakeshore in Maine. - North. J. Appl. For. 7: 114-117.

Lambert, J. D. \& Hannon, S. J. 2000. Short-term effects of timber harvest on abundance, territory characteristics, and pairing success of ovenbirds in riparian buffer strips. - The Auk 117: 687-698.

LaRue, P., Bélanger, L. \& Huot, J. 1995. Riparian edge effects on boreal balsam fir bird communities. - Can. J. For. Res. 25: 555-566.

Meiklejohn, B. A. \& Hughes, J. W. 1999. Bird communities in riparian buffer strips of industrial forests. - Am. Midl. Nat. 141: 172-184.

Nilsson, C. 1992. Conservation management of riparian communities. Pp. 352-372 in Ecological principles of nature conservation (Hansson, L. Ed.). Elsevier Applied Science, London and New York.

Stauffer, D. F. \& Best, L. B. 1980. Habitat selection by birds of riparian communities: Evaluating effects of habitat alterations. - J. Wildl. Manag. 44: 1-15.

Thingstad, P. G. 1997. Annual and local reproductive variations of a Pied Flycatcher Ficedula hypoleuca population near a subalpine lake in Central Norway. - Ornis Fennica 74: 39-49.

Tømmerås, B. Å., Wilmann, B., Ødegaard, F., Gjershaug, J. O., Breistein, J., Abildsnes, J., Prestø, T., Aakra, K. \& Krogstad, S. 2000. Effekter av fragmentering på biodiversitet $\mathrm{i}$ granskog. - NINA Fagrapport 40: 1-89. (In Norwegian).

Virkkala, R. 1991. Population trends of forest birds in a Finnish Lapland landscape of large habitat blocks: Consequences of stochastic environmental variation or regional habitat alteration? - Biol. Conserv. 56: 223-240.

Whitaker, D. M., Carroll, A. L. \& Montevecchi, W. A. 2000. Elevated numbers of flying insects and insectivorous birds in riparian buffer strips. - Can. J. Zool. 78: 740-747.

Whitaker, D. M.\& Montevecchi, W.A. 1999. Breeding bird assemblages inhabiting riparian buffer strips in Newfoundland, Canada. - J. Wildl. Manag. 63: 167-179. 